\title{
Epidermal growth factor receptor levels are reduced in mice with targeted disruption of the protein kinase $\mathbf{A}$ catalytic subunit Morten P Oksvold*1, Ane Funderud ${ }^{2}$, Anne-Katrine Kvissel2 ${ }^{2}$ Ellen Skarpen ${ }^{1}$, Heidi Henanger ${ }^{2}$, Henrik S Huitfeldt ${ }^{1}$, Bjørn S Skålhegg ${ }^{2}$ and Sigurd Ørstavik ${ }^{2}$
}

\author{
Address: ${ }^{1}$ Institute of Pathology, Rikshospitalet University Hospital, University of Oslo, Norway and ${ }^{2}$ Institute for Basic Medical Sciences, \\ Department of Nutrition, University of Oslo Medical School, Norway \\ Email: Morten P Oksvold* - moroks@rr-research.no; Ane Funderud - ane.funderud@medisin.uio.no; Anne- \\ Katrine Kvissel - a.k.kvissel@medisin.uio.no; Ellen Skarpen - ellen.skarpen@medisin.uio.no; Heidi Henanger - heidi8613@gmail.com; \\ Henrik S Huitfeldt - henrik.huitfeldt@medisin.uio.no; Bjørn S Skålhegg - b.s.skalhegg@medisin.uio.no; \\ Sigurd Ørstavik - sigurdorstavik@hotmail.com \\ * Corresponding author
}

Published: I April 2008

BMC Cell Biology 2008, 9:16 doi:10.1186/1471-2121-9-16

This article is available from: http://www.biomedcentral.com/I47I-2/2I/9/16

(c) 2008 Oksvold et al; licensee BioMed Central Ltd.

This is an Open Access article distributed under the terms of the Creative Commons Attribution License (http://creativecommons.org/licenses/by/2.0), which permits unrestricted use, distribution, and reproduction in any medium, provided the original work is properly cited.

\begin{abstract}
Background: Epidermal Growth Factor Receptor (EGFR) is a key target molecule in current treatment of several neoplastic diseases. Hence, in order to develop and improve current drugs targeting EGFR signalling, an accurate understanding of how this signalling pathway is regulated is required. It has recently been demonstrated that inhibition of CAMP-dependent protein kinase (PKA) induces a ligand-independent internalization of EGFR. Cyclic-AMP-dependent protein kinase consists of a regulatory dimer bound to two catalytic subunits.
\end{abstract}

Results: We have investigated the effect on EGFR levels after ablating the two catalytic subunits, $C \alpha$ and $C \beta$ in two different models. The first model used targeted disruption of either $C \alpha$ or $C \beta$ in mice whereas the second model used $C \alpha$ and $C \beta$ RNA interference in HeLa cells. In both models we observed a significant reduction of EGFR expression at the protein but not mRNA level.

Conclusion: Our results suggest that PKA may represent a target that when manipulated can maintain EGFR protein levels at the single cell level as well as in intact animals.

\section{Background}

Ligand binding to EGFR induces tyrosine transphosphorylation, and phosphotyrosines serve as binding sites for various signalling molecules. Association of these molecules with the EGFR leads to their activation, and initiation of signalling cascades culminating in a variety of responses. The activated EGFR is internalized shortly after ligand binding, and is processed in the endosomal pathway. The receptor is signalling competent when residing in the plasma membrane [1], but also during intracellular receptor trafficking $[2,3]$. Defects in the internalization process and degradation pathways for the EGFR family members have been associated with cell transformation and oncogenesis [4]. It has been demonstrated that cAMPdependent protein kinase (PKA) is involved in the transduction of mitogenic signals [5], and interactions between PKA and the activated EGFR have been demonstrated [6]. Previous studies have shown that the EGFR is a substrate 
for PKA $[7,8]$. Phosphorylation of the EGFR by PKA on serine residues leads to decreased tyrosine kinase activity and diminished autophosphorylation of the EGFR [9]. Recently, Salazar and Gonzalez [10] showed that PKA basal activity controls EGFR function, both at the cell surface and during down-regulation.

PKA is a holoenzyme consisting of two regulatory ( $R$ ) subunits bound together in a dimer, with one catalytic (C) subunit bound to each R-subunit [11]. In the absence of CAMP, the R-subunits will inhibit the $\mathrm{C}$ subunits, but a conformational change in the R-subunit is induced by binding of CAMP, releasing the $\mathrm{C}$ subunit which is then active. In mammals, four genes encode different isoforms of the R-subunits, RI $\alpha$, RI $\beta$, RII $\alpha$ and RII $\beta$, and three different genes encode three isoforms of $\mathrm{C}, \mathrm{C} \alpha, \mathrm{C} \beta$ and PRKX [12]. The $\mathrm{C} \alpha$ and $\mathrm{C} \beta$ isoforms are closely related in protein sequence, whereas the PRKX sequence is divergent from $C \alpha$ and $C \beta$. The $C \alpha$ and the $C \beta$ genes encode tissuespecifically expressed splice variants designated $C \alpha 1$, $\mathrm{C} \alpha 2, \mathrm{C} \beta 1, \mathrm{C} \beta 2, \mathrm{C} \beta 3, \mathrm{C} \beta 4$, and several $\mathrm{C} \beta 3$ and $4 \mathrm{abc}$ variants [13-20].

Functional features associated with the various $C$ subunits have been studied in genetically null mutated mice. Mutation of the $\mathrm{C} \beta$ gene does not result in any clear phenotype and the mice appear healthy and fertile [21]. By contrast, mutation of the C $\alpha$ gene leads to early postnatal lethality in the majority of the offsprings [22]. The male $\mathrm{C} \alpha \mathrm{KO}$ mice that survive to adulthood are infertile and both male and females show a uniform reduction in size by approximately $30 \%$ compared to their wild type littermates. Size reduction is accompanied by a nearly complete absence of PKA C subunit activity in most tissues, except the brain, where $C$ subunit activity is slightly elevated due to $C \beta$ compensation. Moreover, growth retardation in the $\mathrm{C} \alpha$ $\mathrm{KO}$ mice may be growth hormone (GH)-dependent because mRNA levels of GH-dependent molecules such as IGF-1 (insulin like growth factor 1) and MUPs (major urinary protein) were significantly reduced.

The cAMP/PKA signaling pathway may be activated through stimulation of a number of different receptors that regulate a vast number of cellular processes. These include metabolism, gene expression, ion channel conductivity, cell growth and division as well as cell differentiation $[23,24]$. Since the significance of PKA-dependent interaction with the EGFR is poorly understood, we embarked on a study to investigate the location and levels of EGFR in PKA C subunit null mutated mice. Our results indicate that the level and localization of EGFR are closely correlated with the level and activities of PKA C subunit.

\section{Results \\ EGFR levels in mice are regulated by PKA catalytic subunits}

EGFR trafficking has been demonstrated to be regulated by PKA activity, and inhibition of PKA activity results in internalization of the EGFR in neuroblastoma N2a cells [10]. We therefore decided to examine the localization of EGFR in the livers of mice depleted of either PKA C $\alpha$ or C $\beta$ $[22,21]$. Livers from wt and $\mathrm{KO} \mathrm{C} \alpha$ and $\mathrm{C} \beta$ mice were dissected and the morphology and size examined. As illustrated in Figure 1A, livers from $\mathrm{C} \alpha \mathrm{KO}$ mice were smaller compared to wt mice. Frozen sections of liver from wt and $\mathrm{KO}$ of $\mathrm{C} \alpha$ and $\mathrm{C} \beta$ were stained using anti-EGFR and visualized using confocal immunofluorescence microscopy. We observed a reduction in membrane association as compared to the wild-type littermates for both $\mathrm{C} \alpha \mathrm{KO}$ and $\mathrm{C} \beta \mathrm{KO}$ (Figure 1B). This led us to believe that abolished expression of either $\mathrm{C} \alpha$ or $\mathrm{C} \beta$ led to a decrease in total EGFR levels in liver.

To test this hypothesis, cell extracts were prepared from liver and brain of $\mathrm{C} \alpha$ and $\mathrm{C} \beta \mathrm{KO}$ animals and wt and heterozygous littermates, separated by SDS-PAGE for analysis by Western immunoblotting using anti-EGFR (Figure 1C, upper panel). In liver but not brain, a clear reduction in total EGFR could be observed in both $\mathrm{C} \alpha \mathrm{KO}$ and $\mathrm{C} \beta \mathrm{KO}$ animals, as compared to their wild-type mice (Figure $1 \mathrm{C}$, upper panel). This was also demonstrated by immunohistochemical staining of frozen brain sections (data not shown). To correlate this to total PKA C expression, similar Western blots were analyzed using an anti-PKA C antibody, demonstrating a clear reduction of PKA immunoreactive protein in both $\mathrm{C} \alpha \mathrm{KO}$ and $\mathrm{C} \beta \mathrm{KO}$ animals, as compared to their wild-type and heterozygous littermates (Figure 1C, middle panel). The expression and stability of another EGFR family member, ErbB2, was not affected by PKA depletion (Figure 1C, lower panel), demonstrating specificity of PKA-dependent regulation of the EGFR. EGFR expression levels in heart, kidney, intestine and lung tissue from mice was also analyzed, but due to low EGFR protein levels we were unable to draw conclusions regarding comparison of EGFR protein levels in wt versus knock out animals (data not shown).

Our observation that $\mathrm{C} \beta \mathrm{KO}$ animals displayed decreased expression of EGFR was unexpected as previous results have indicated that liver mainly expresses the C $\alpha$ isoform [25]. We therefore examined the total PKA activity in cell extracts of livers from both $\mathrm{C} \alpha$ and $\mathrm{C} \beta \mathrm{KO}$ animals and their wt littermates using a Kemptide based phosphotransferase assay (Figure 1D). Both $\mathrm{C} \alpha$ and $\mathrm{C} \beta \mathrm{KO}$ animals demonstrated a similar reduction in total PKA activity of more than $70 \%$, indicating that both $\mathrm{C} \alpha$ and $\mathrm{C} \beta$ contribute significantly to total PKA activity in mouse liver. 
a

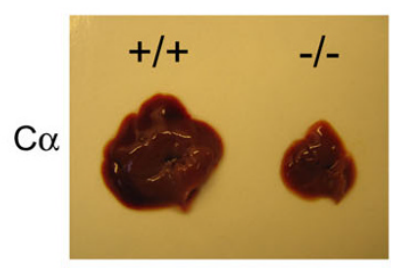

$\mathrm{C} \beta$

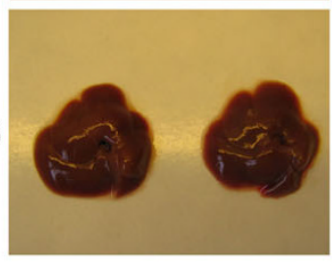

b

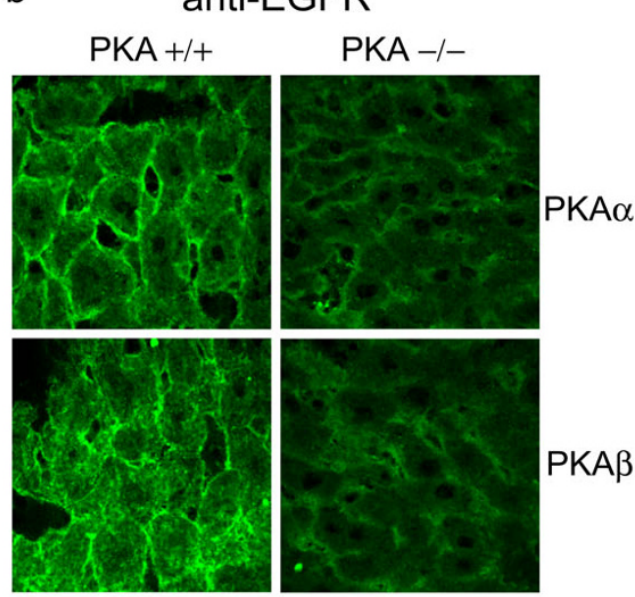

C

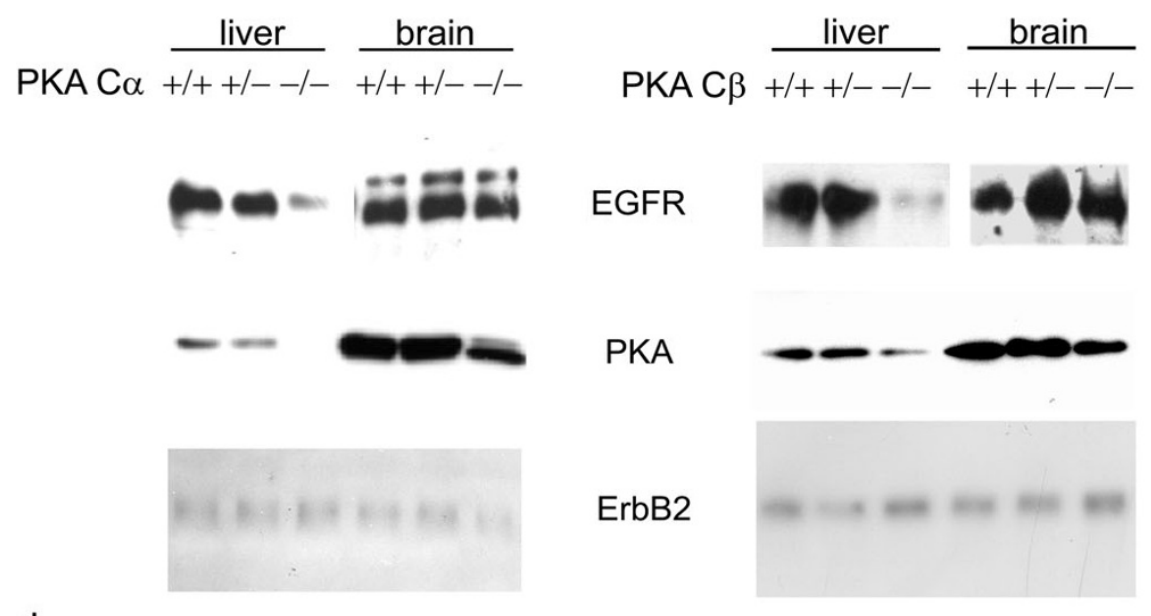

d

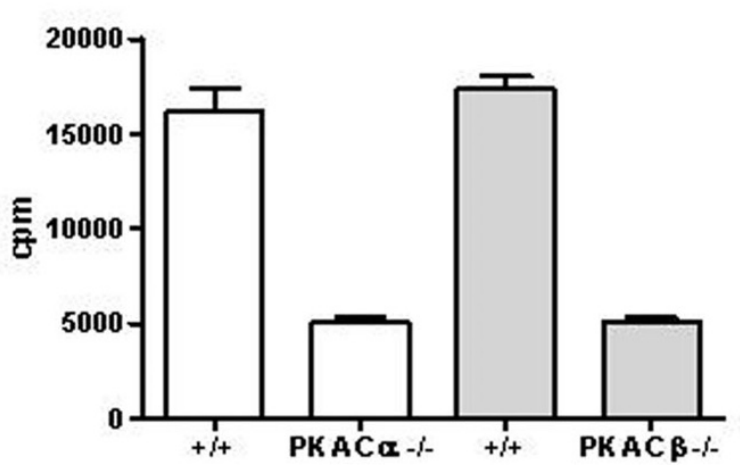

Figure I

Effect of PKA C $\alpha$ or C $\beta$ ablation on EGFR expression. (a) Comparison of liver from wild type and PKA C $\alpha$ and C $\beta$ ablated mice. PKA C $\alpha$ KO mice showed a clear uniform reduction in size. (b) Confocal immunofluorescence microscopy of frozen liver sections stained by sheep anti-EGFR and Cy3-conjugated donkey anti-sheep antibodies. (c) Western immunoblotting analysis of EGFR expression in liver and brain from wt (+/+), heterozygote $(-/+)$, and $C \alpha$ and $C \beta K O(-/-)$ mice. Immunoblots were incubated with sheep anti-EGFR, rabbit anti-pan PKA $C$ and mouse anti-PKA C, and rabbit anti-erbB2. Secondary HRP-conjugated anti-lgG antibodies were used for detection. (d) PKA kinase activity in mouse liver. Activity was assayed by phosphorylation of the PKA-specific substrate Kemptide using $\gamma$-[32P]ATP. The assay was performed in the presence of cAMP. Activity was measured by liquid scintillation in $3 \mathrm{ml}$ Opti-fluor. Values are given as counts per minute (cpm). 
EGFR expression levels may be regulated at several stages including at the level of transcription, mRNA processing, translation as well as post translation. In order to examine how the EGFR level is regulated, we compared the EGFR mRNA levels in liver of wild type animals with $\mathrm{C} \alpha$ and $\mathrm{C} \beta$ $\mathrm{KO}$ animals, using real-time PCR.

Deficiency of the PKA C $\alpha$ or $C \beta$ isoforms did not change expression of EGFR mRNA (Figure 2A,B, respectively). This demonstrated that the reduction in EGFR-levels in $\mathrm{C} \alpha$ and $\mathrm{C} \beta \mathrm{KO}$ mice livers was not due to reduced mRNA expression, and indicates that a modulation of EGFR at

a

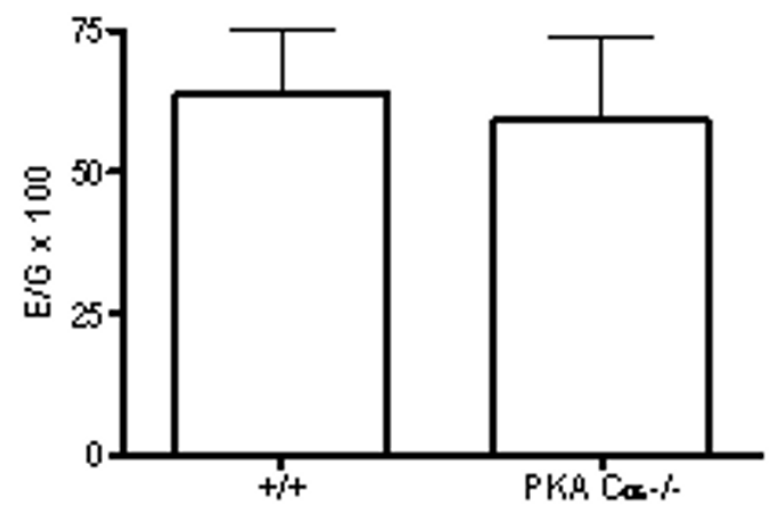

b

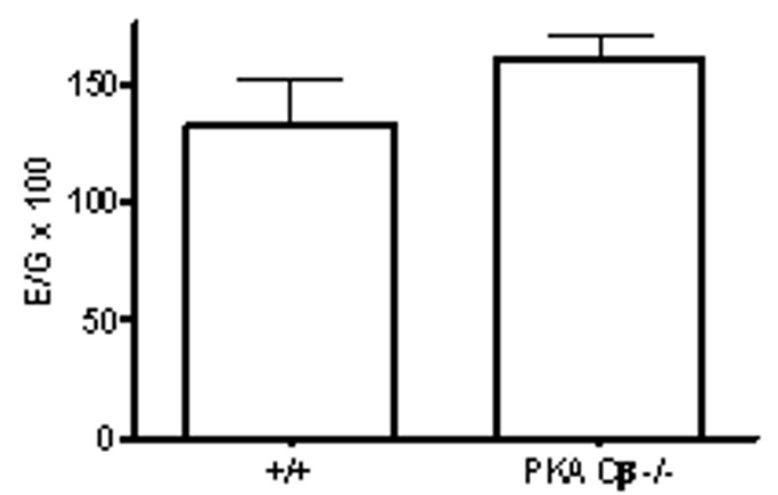

Figure 2

EGFR mRNA expression in livers from wt, $\mathbf{C} \alpha$ and $\mathbf{C} \beta$ KO mice. The level of EGFR cDNA was determined by real time RT-PCR. The levels of EGFR mRNA expression in $\mathrm{C} \alpha$ $K O$ versus wt livers (a) and $C \beta$ KO versus wt livers (b) were calculated as relative copy numbers normalized against GAPDH mRNA. Relative EGFR mRNA expression was calculated using the formula $(E / G) \times 100$, where $E$ and $G$ are the relative copy numbers of EGFR and GAPDH mRNA, respectively. The results are given as $+/-$ SEM where $n=3$. post-transcriptional level is responsible for the reduction in EGFR.

\section{Ablation of PKA C $\alpha$ or $C \beta$ reduces the growth in mice}

Previously it has been reported that $\mathrm{C} \alpha \mathrm{KO}$ mice are growth retarded and thus have significantly reduced body size compared to their wild type littermates [22]. In this study an early postnatal lethality in the majority of $\mathrm{C} \alpha \mathrm{KO}$ mice was reported. However, a small percentage of $\mathrm{C} \alpha \mathrm{KO}$ mice survived to adulthood [22]. From our preliminary studies with $\mathrm{C} \alpha \mathrm{KO}$ mice, we hypothesized that there was a link between body size reduction and a reduced EGFR expression level in these animals. Previous studies did not detect any obvious differences in phenotype of $\mathrm{C} \beta \mathrm{KO}$ mice [21]. In order to examine if there are any decreases in body size for the $\mathrm{C} \beta$ mice, we compared body weight of wt, $\mathrm{C} \alpha$ and $\mathrm{C} \beta$ mice at different ages using multiple linear regression in SPSS. As expected, the $\mathrm{C} \alpha \mathrm{KO}$ mice were significantly smaller $(\mathrm{P}<0.0001)$ than their wt littermates at all ages (Figure 3 ). The analysis showed a significant correlation between body weight and genotype when adjusted for age $(P<0.0001)$. This was also the case with the $\mathrm{C} \beta$ KO mice $(\mathrm{P}<0.0001)$. It should however be mentioned that this reduction was much less profound when compared to the $\mathrm{C} \alpha \mathrm{KO}$ littermates. Based on this we suggest a redundant function of $\mathrm{C} \alpha$ and $\mathrm{C} \beta$ in regulating body size which may be associated with reduced expression of EGFR.

\section{PKA $C \alpha$ and $C \beta$ are involved in the regulation of EGFR expression in HeLa cells}

In order to further substantiate the correlation between depletion of PKA catalytic isoforms and expression of the EGFR protein, we studied HeLa cells treated with siRNA directed against $\mathrm{C} \alpha$ and $\mathrm{C} \beta$. Following $24 \mathrm{~h}$ incubation with either $\mathrm{C} \alpha$ or $\mathrm{C} \beta$-specific siRNA PKA specific kinase activity was measured by a Kemptide based phosphotransferase assay. This demonstrated a 30\% reduction in PKA kinase activity (Figure 4A). When EGFR mRNA levels in the same samples were analyzed by RT-PCR, it was clear that the reduced activity of PKA did not result in a downregulation of EGFR mRNA (Figure 4B). In contrast the protein level of EGFR was significantly decreased as measured by immunoreactive protein in cell extracts of control cells and cells treated with siRNA against $\mathrm{C} \alpha$ and $\mathrm{C} \beta(\mathrm{C}$, $\mathrm{C} \alpha$ and $\mathrm{C} \beta$, respectively, Figure 4C).

\section{Discussion}

The data presented here have demonstrated in two different models that depletion of $\mathrm{C} \alpha$ or $\mathrm{C} \beta$ induces a reduction of EGFR protein levels, and that this reduction is not due to decreased level of EGFR mRNA.

A recent report by [10] demonstrated that membrane expression of EGFR was inhibited by the PKA inhibitor 


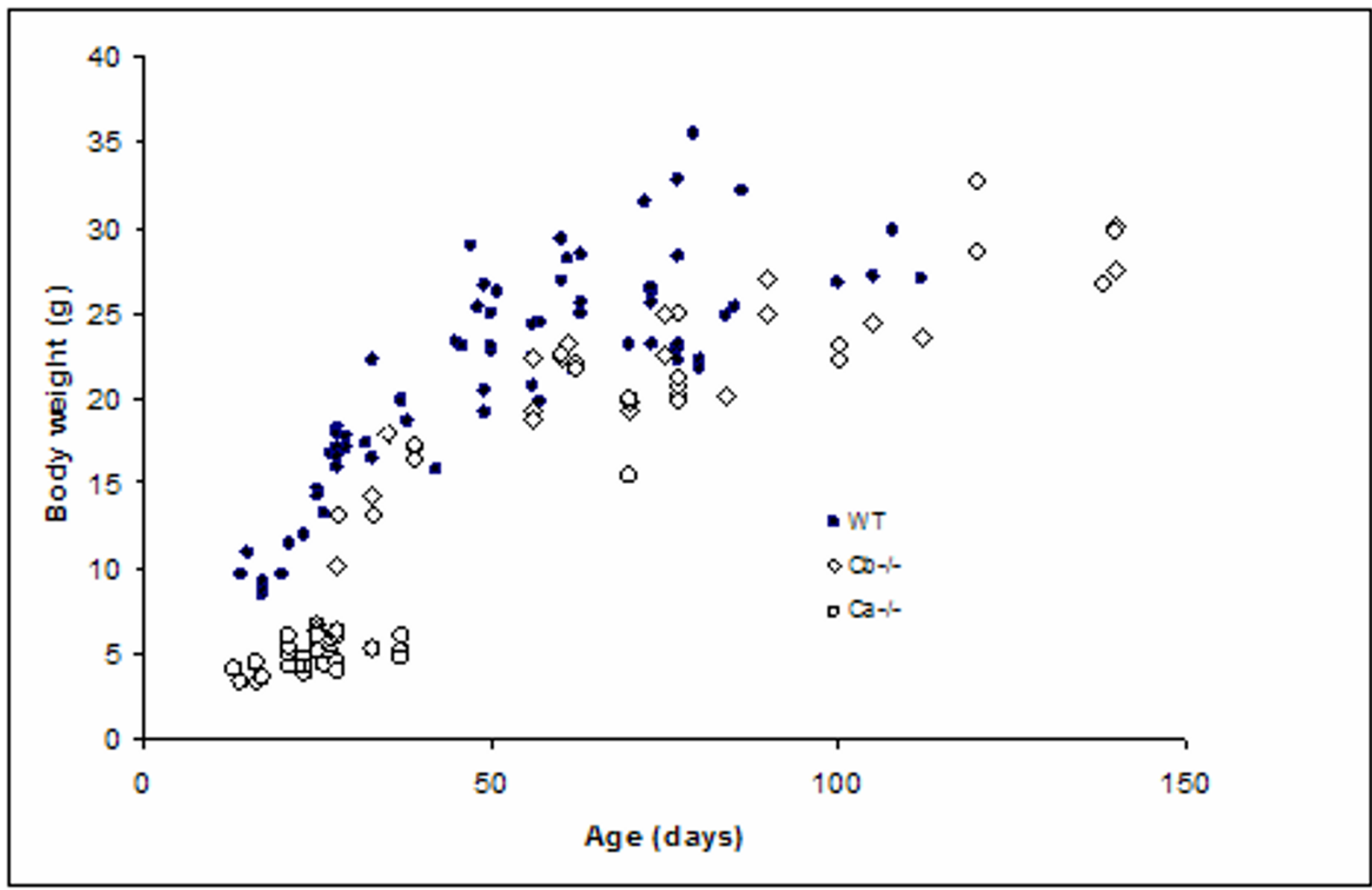

Figure 3

Postnatal growth of $\mathrm{C} \alpha$ and $\mathrm{C} \beta \mathrm{KO}$ mice: the figure depicts the correlation between age and measured body weight of WT mice $(n=76)$ versus $C \alpha K O(n=32)$ and $C \beta K O(n=42)$ mice. Linear regression analysis showed that both $\mathrm{C} \alpha$ and $C \beta$ KO mice have a significantly lower body weight when compared to WT mice $(P<0,000 \mathrm{I})$ when adjusted for age.

H89 through increased internalization and endosome arrest of the EGFR in neuroblastoma N2a cells. Such an effect could be observed after 4 hours of H89 treatment. As H89 is known to have a broader inhibitory specificity [26-28], these observations did not necessarily prove involvement of PKA in maintaining EGFR levels. Here we demonstrate that EGFR was reduced in both mouse liver and HeLa cells after depletion of $\mathrm{C} \alpha$ and $\mathrm{C} \beta$, respectively. The reduced levels of EGFR were not due to reduction in EGFR mRNA, as demonstrated in both HeLa cells depleted of either $\mathrm{C} \alpha$ or $\mathrm{C} \beta$, as well as mouse livers isolated from $\mathrm{C} \alpha$ and $\mathrm{C} \beta \mathrm{KO}$ mice. The results from mouse $\mathrm{C} \alpha$ and $\mathrm{C} \beta \mathrm{KO}$ livers indicated a relative reduction in staining for EGFR along the plasma membrane, as well as a general reduction of immunoreactive protein. This is contrary to the previous observation that H89 and thus inhibition of PKA induces an increased internalization of EGFR, which suggests that reduced PKA activity leads to degradation of EGFR. Our results demonstrate in mouse liver as well as HeLa cells, that a reduction in total PKA activity either through elimination of $\mathrm{C} \alpha$ or $\mathrm{C} \beta$ leads to a reduced expression of EGFR protein. This was not observed in the brain of neither $\mathrm{C} \alpha$ nor $\mathrm{C} \beta \mathrm{KO}$ mice. The explanation for this may be that brain has a much higher levels of both PKA C $\alpha$ and C $\beta$ than liver and HeLa cells $[29,15]$. Thus, one C subunit may be expected to compensate for the loss of activity of the other isoform. Based on that we postulate that protein levels of EGFR depend on a certain threshold level of PKA and that this effect may not be isoform-specific. Such a hypothesis is in part supported by observations made by Huang and colleagues [30]. In mice with one or two mutant $\mathrm{C}$ subunit alleles $(\mathrm{C} \alpha-/-$ and $\mathrm{C} \beta+/+$ or $\mathrm{C} \alpha+/+$ and $\mathrm{C} \beta-/-$ or $\mathrm{C} \alpha-/+$ and $\mathrm{C} \beta-/+$ ), either of them were born with apparent embryonic defects. However, when deleting three alleles (either $\mathrm{C} \alpha-/-$ and $\mathrm{C} \beta$ $-/+$, or $C \alpha-/+$ and $C \beta-/-$ ) they demonstrated a $100 \%$ penetrant spinal neural tube defect and spina bifida. This suggests that the $\mathrm{C}$ gene dose in the brain is sufficient to 
a

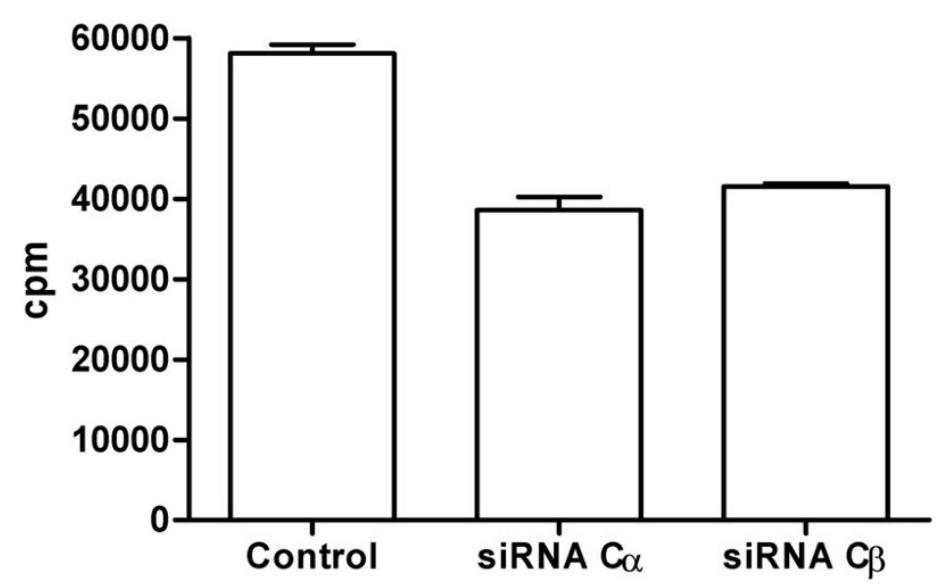

b

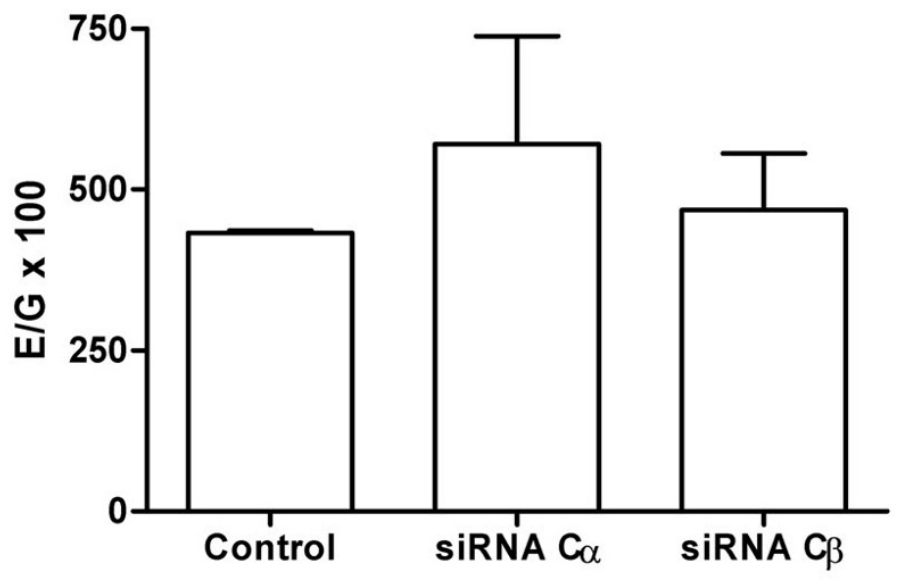

C

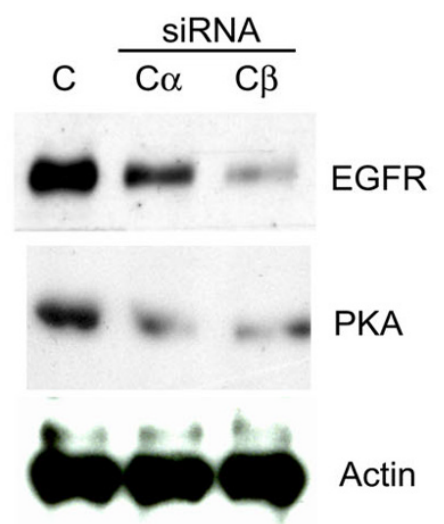

Figure 4

Levels of EGFR protein correlate with levels and activities of $\mathbf{C} \alpha$ and $\mathbf{C} \beta$ in HeLa cells. (a) HeLa cells incubated with RNAi against $C \alpha$ and $C \beta$ and monitored for PKA-specific phosphotransferase activity in cell extracts of I mg/mL. Relative values given as counts per minute (cpm). (b) Relative EGFR mRNA expression levels were measured by RT-PCR and are given as $E / G \times 100$ where $E$ and $G$ are the relative copy numbers of EGFR and GAPDH mRNA, respectively. The results are given as $+/$ - SEM where $n=3$. (c) Western immunoblotting analysis of expression of EGFR and PKA C. An anti-actin antibody was applied to ensure equal loading. 
rescue a defect irrespective of the isoform, implying $\mathrm{C} \alpha$ and $\mathrm{C} \beta$ redundancy in the brain. Furthermore, in our experiments we observed that the regulatory effects on the EGFR levels were apparent even without prior stimulation of endogenous CAMP formation. This observation may be explained in several ways including that of chronic levels of endogenous CAMP, or free $\mathrm{C}$ subunits which activity is stimulated independently of cAMP. The latter hypothesis is supported by several studies demonstrating that $\mathrm{C}$ subunits when bound to proteins other than the PKA R subunit, the $\mathrm{C}$ subunits may be regulated in a cAMP independent fashion $[31,32]$.

The fact that $\mathrm{C} \beta$ ablated mice also displayed decreased levels of EGFR indicates that $C \beta$ plays a role in mouse liver, despite previous data indicating low levels of $C \beta$ in mouse liver [15]. This was further substantiated by measurement of PKA activity in mouse liver, demonstrating reduced activity in both $\mathrm{C} \alpha$ and $\mathrm{C} \beta$ KO livers. As the sensitivity of Western blotting and mRNA measurements of $C \alpha$ and $C \beta$ will vary, our measurements of activity in $\mathrm{KO}$ mice is probably a better indication of the relative contribution of total $\mathrm{C}$ activity from the different isoforms. The reduction in $\mathrm{C}$ activity in $\mathrm{C} \alpha \mathrm{KO}$ was $70 \%$, while the reduction in $\mathrm{C}$ activity in $\mathrm{C} \beta \mathrm{KO}$ mice was also $70 \%$. This can best be explained by the presence of satiable PKA inhibitors, like endogenous PKI.

The fact that EGFR levels were reduced in the liver of $C \beta$ $\mathrm{KO}$ mice is the first observation of a $C \beta$-dependent phenotype affecting non-nervous tissues. However, we were also able to demonstrate a small but significant reduction in size of the $C \beta$ ablated mice compared to the wt mice, suggesting that the $\mathrm{C} \beta$ subunit may influence growth regulation as has been demonstrated for the C $\alpha$ subunit. The $\mathrm{C} \alpha$ ablated mice showed a growth retardation phenotype consistent with disruption of the GH/IGF-I endocrine system, and while GH-hormone levels were normal, IGF-I mRNA and major urinary proteins (MUPs) levels were reduced, indicating a partial resistance to GH [22]. It has been reported that $\mathrm{C} \alpha$ ablated mice are reduced in size by approximately $30 \%$ and approximately $90 \%$ die before puberty [22]. $\mathrm{C} \beta$ ablated mice by contrast only show a very small reduction in size and they also differ from the $\mathrm{C} \alpha$ mice in that offspring normally survive to adulthood. It is tempting to suggest that $C \beta$ and $C \alpha$ have redundant effects. Moreover, this may also suggest that cellular signaling pathways involved in growth regulation are merely dependent on a certain level of PKA activity for proper function, rather than isoform-specific effects of $\mathrm{C} \alpha$ and $\mathrm{C} \beta$. As $\mathrm{C} \alpha$ is the most abundant $\mathrm{C}$ subunit in non-nervous tissues, disruption of $\mathrm{C} \alpha$ would result in more severe effects in the whole animal than the ablation of the gene for the less abundant $C \beta$ subunit.
High levels of EGFR are associated with many tumors with poor prognostic features. EGFR itself and its downstream signalling pathways are promising targets for anti-tumour drugs [33]. PKA has also been proposed as a possible target for cancer therapy, and the therapeutic potential of the combined blockade of EGFR and PKA has been discussed [34]. With respect to cancer therapy, the focus has been set on the regulatory isoforms of PKA. Site-selective cAMP analogue 8-Cl-cAMP and a series of modified antisense oligonucleotides targeting the PKA RI $\alpha$ subunit have been applied without conclusive effects [35-37]. However, the effects of the cAMP analog 8-Cl-cAMP may be mediated by metabolite rather than the CAMP analog itself, suggesting that PKA is not involved.

\section{Conclusion}

The data presented here have demonstrated in two different models that depletion of $\mathrm{C} \alpha$ or $\mathrm{C} \beta$ induces a reduction of EGFR protein levels, and that this reduction is not due to decreased level of EGFR mRNA. Our results have demonstrated that PKA activity contributes to maintaining EGFR levels in cells and in vivo, thus suggesting a crosstalk between the CAMP and EGF pathways, making the PKA C subunit a potential target for future therapies.

\section{Methods \\ Breeding and genotyping of PKA C $\alpha$ and $\mathrm{C} \beta$ null mutated mice}

Mice ablated (knock-out, KO) for the $\mathrm{C} \alpha$, and $\mathrm{C} \beta$ genes were kindly contributed by Professor G. Stanley MckKnight (Department of Pharmacology, University of Washington School of Medicine, Seattle, 98195, USA.) $[22,21]$. All use of animals has been approved and registered by the Norwegian Animal Research Authority. The mice strains were both on a mixed C57BL/ $6 \times 129$ background and were treated and bread identically. Animals were housed in a temperature controlled $\left(22^{\circ} \mathrm{C}\right)$ facility with a strict 12 hour light/dark cycle, and allowed the RM1 diet (Special Diet Services Ltd, Witham, Essex, UK) and water ad libitum before euthanasia. Heterozygote animals were crossed and offspring genotyped by PCR. The $\mathrm{C} \alpha$ and $\mathrm{C} \beta \mathrm{KO}$ allele were detected as previously described $[22,38]$.

\section{Immunofluorescence microscopy}

Immunohistochemical analysis of EGFR distribution and expression in liver sections from 6 weeks old wild type and PKA C $\alpha$ and $\mathrm{C} \beta$ KO mice was performed on $8 \mu \mathrm{m}$ thick sections fixed in ethanol as described previously [39]. Sections were incubated with a sheep anti-EGFR antibody (Fitzgerald) over night, following detection with a Cy2-conjugated donkey anti-sheep IgG antibody (Jackson Immunoresearch). Sections were examined using a Leica TSC XP confocal microscope (Leica Microsystems) equipped with an $\operatorname{Ar}(488 \mathrm{~nm})$ and two $\mathrm{He} / \mathrm{Ne}$ (543 and 
$633 \mathrm{~nm}$ ) lasers. A Plan apochromat 100×/1.4 oil objective was used.

\section{Western immunoblotting analysis}

Liver and brain from 6 weeks old mice, and HeLa cells, were lysed in Tris lysis buffer, $\mathrm{pH} 7.4(50 \mathrm{mM}$ Tris- $\mathrm{HCl}$, $150 \mathrm{mM} \mathrm{NaCl}, 1 \mathrm{mM}$ EDTA, $1 \% \mathrm{NP}-40,1 \mathrm{mM} \mathrm{Na}_{3} \mathrm{VO}_{4}$, $20 \mathrm{mM} \mathrm{NaF}, 1 \mu \mathrm{g} / \mathrm{ml}$ chymostatin, leupeptin and antipain. Liver and brain were homogenized using a Mini beadbeater (Biospec products) with $1 \mathrm{~mm}$ silica beads for $20 \mathrm{sec}$ at $4{ }^{\circ} \mathrm{C}$. Lysates were incubated on ice for minimum $15 \mathrm{~min}$, and cell debris and nuclei removed by centrifugation at $8000 \mathrm{rpm}$ at $4{ }^{\circ} \mathrm{C}$ for $10 \mathrm{~min}$. The Dc protein detection kit was applied to measure and adjust total protein concentrations. A $5 \times$ protein sample buffer stock solution (2\% SDS, 10\% glycerol, $0.02 \%$ bromophenol blue and $2 \% \beta$-mercaptoethanol, final concentrations) was mixed with the lysates. The samples were boiled for $5 \mathrm{~min}$, and proteins separated by SDS-PAGE in $6 \%$ and $10 \%$ gels. Proteins were transferred wet to nitrocellulose membranes, rinsed in ice-cold Tris-buffered saline [TBS; $10 \mathrm{mM}$ Tris, $\mathrm{pH}$ 8.0, and $150 \mathrm{mM} \mathrm{NaCl}$ and incubated in blocking buffer (TBS containing 5\% dry milk) for $30 \mathrm{~min}$ at RT. The membranes were incubated over night at $4^{\circ} \mathrm{C}$ with donkey anti-EGFR (Fitzgerald), rabbit anti-pan C (anti-PKA $\alpha$ cat, Santa Cruz biotechnology) and mouse anti-PKA C (BD Biosciences), and anti-erbB2 (Zymed). Immunoreactive proteins were recognized using anti-sheep $\operatorname{IgG}$ and rabbit IgG conjugated to HRP (Jackson Immunoresearch and Sigma, respectively). Proteins were detected using HRP-conjugated donkey anti-sheep IgG and anti-mouse IgG (Jackson Immunoresearch), and goat anti-rabbit IgG (Sigma) for $90 \mathrm{~min}$ at RT. All antibodies were diluted in TBS containing $1 \% \mathrm{w} / \mathrm{v}$ dry milk and $0.01 \%$ thimerosal. The filters were washed in TBS, and antigens were visualized by the enhanced chemiluminescence (ECL) method with Hyperfilm MP (Amersham Biosciences).

\section{Phosphotransferase assay}

The PKA kinase activity in liver or HeLa cell was assayed by phosphorylation of the PKA-specific substrate Kemptide (Peninsula Laboratories) using $\gamma$-[ $\left.{ }^{32} \mathrm{P}\right]$ ATP (Amersham Biosciences). The assay was performed in the presence of cAMP. Cells were washed in PBS, harvested by scraping, solubilised in $200 \mu \mathrm{l}$ homogenising buffer (5 $\mathrm{mM} \mathrm{KH}{ }_{2} \mathrm{PO}_{4}, 5 \mathrm{mM} \mathrm{K} \mathrm{HPO}_{4}, 1 \mathrm{mM}$ EDTA, $250 \mathrm{mM}$ sucrose and protease inhibitor cocktail (Roche Diagnostics), $\mathrm{pH} 6.8$ ) and sonicated for $3 \times 5 \mathrm{~s}$. The homogenate was cleared by centrifugation at $16,000 \times g$ for $10 \mathrm{~min}$ at $4{ }^{\circ} \mathrm{C}$. Total protein amount was estimated by Dc protein assay (BioRad). Ten-micro liter homogenate was used in an assay mixture earlier described [40]. Reactions were performed at $30^{\circ} \mathrm{C}$, and stopped after 9 min by transfer to P81 phosphocellulose paper (Whatman). Filters were washed in $75 \mathrm{mM}$ phosphorus acid for $1 \mathrm{~h}$ at room tem- perature, incubated with $96 \%$ ethanol for $10 \mathrm{~min}$ and dried. Activity was measured by liquid scintillation in 3 ml Opti-fluor ${ }^{\mathrm{Tm}}$ (Packard BioScience).

\section{RT-PCR}

Mouse liver from 6 weeks old mice was homogenized as described above. HeLa cells were washed in PBS, harvested by scraping and subjected to total RNA isolation using the RNeasy Minikit (Qiagen). RNA ( $1 \mu \mathrm{g})$ was used to make first-strand cDNA by Reverse Transcription system (Promega). Titration with cDNA was performed demonstrating that the method was able to detect small changes in sample size. The cDNA was used as templates in PCRs with primer combinations specific for mouse EGFR (5'-TCT TCA AGG ATG TGA AGT GTG-3', 5'-TGT ACG CTT TCG AAC AAT GT-3'). Human EGFR Primers used for EGFR amplification in HeLa cells were: 5'-GCC AAG GCA CGA GTA ACA AGC-3', 5'-AGG GCA ATG AGG ACA TAA CC-3'. The PCR reaction was carried out in a 20 $\mu \mathrm{l}$ final volume containing the following: $\mathrm{H}_{2} \mathrm{O}$ up to 20 $\mu \mathrm{l} ; 2.4 \mu \mathrm{l} 25 \mathrm{mmol} / \mathrm{l} \mathrm{MgCl}_{2} ; 1 \mu \mathrm{l} 10 \mathrm{pmol}$ sense primer, 1 $\mu l 10$ pmol antisense primer, $2 \mu \mathrm{l}$ LC-Faststart master mix, and $4 \mu \mathrm{l} \mathrm{cDNA}$. PCR cycles were as follows: $94^{\circ} \mathrm{C}$ for 120 $\mathrm{s}$ (initial denaturation), $95^{\circ} \mathrm{C}$ for $5 \mathrm{~s}, 58^{\circ} \mathrm{C}$ for $5 \mathrm{~s}$, and $72^{\circ} \mathrm{C}$ for $13 \mathrm{~s}$ ( 45 cycles).

\section{Cell culture and RNAi transfection}

HeLa cells were cultured in Dulbecco's modified Eagle's medium supplemented with $10 \%$ fetal bovine serum (Gibco-BRL), $2 \mathrm{mM} \mathrm{l-glutamine} \mathrm{and} \mathrm{maintained} \mathrm{at} 37^{\circ} \mathrm{C}$ and $5 \% \mathrm{CO}_{2}$. The cells were seeded in $60-\mathrm{mm}$ dishes and all transfections and experiments were initiated two days after plating. Two siRNA duplexes protected by two 3'overhanged (2'-deoxy) thymidines (dT) were synthesized by Dharmacon Research. These oligonucleotides are: PKA C $\alpha$ : 5'-AAG CUC CCU UCA UAC CAA AGU-3', PKA C $\beta$ : 5'-AAG GUC CGA UUC CCA UCC CAC-3'. HeLa cells were transiently transfected with siRNA against PKA Ca and $C \beta$ using lipofectamine 2000 (Invitrogen) in Optimem medium (Gibco) at the final concentration of 115 nM. Nontargeting (scrambled) siRNA pool (Dharmacon) at the same concentration was used as a control. After 24 h transfection, cell lysates were collected with Tris lysis buffer and total protein concentration was estimated and adjusted by Dc protein assay (Bio-Rad).

\section{Authors' contributions}

MPO carried out most of the experiments, and participated in the design of the study and writing the manuscript. AF carried out the growth analysis. AKK and $\mathrm{HH}$ participated in some of the experiments. ES, HSH, BSS and $S \varnothing$ participated in the design of the study, and writing the manuscript. All authors read and approved the final manuscript. 


\section{Acknowledgements}

We thank Helga Grøsvik and Sissel Eikvar for expert technical assistance. This work was supported by grants from the Research Council of Norway, and the Norwegian Cancer Society, The University of Oslo.

\section{References}

I. Jorissen RN, Walker F, Pouliot N, Garrett TP, Ward CW, Burgess AW: Epidermal growth factor receptor: mechanisms of activation and signalling. Exp Cell Res 2003, 284:3I-53.

2. Di Guglielmo GM, Baass PC, Ou W-J, Posner BI, Bergeron JJM: Compartmentalization of SHC, GRB2 and mSOS, and hyperphosphorylation of Raf-I by EGF but not insulin in liver parenchyma. EMBO J 1994, I 3:4269-4277.

3. Barbier AJ, Poppleton HM, Yigzaw, Mullenix JB, Wiepz GJ, Bertics PJ, Patel TB: Transmodulation of epidermal growth factor receptor function by cyclic AMP-dependent protein kinase. J Biol Chem 1999, 274:|4067-|4073.

4. Ceresa BP, Schmid SL: Regulation of signal transduction by endocytosis. Curr Opin Cell Biol 2000, I 2:204-2I 0.

5. Stork PJ, Schmitt JM: Crosstalk between CAMP and MAP kinase signaling in the regulation of cell proliferation. Trends Cell Biol 2002, I 2:258-266.

6. Tortora G, Ciardiello F: Protein kinase A as target for novel integrated strategies of cancer therapy. Ann NY Acad Sci 2002, 968: $139-147$.

7. Rackoff WR, Rubin RA, Earp HS: Phosphorylation of the hepatic EGF receptor with CAMP-dependent protein kinase. Mol Cell Endocrinol 1984, 34: II3-II9.

8. Ghosh-Dastidar P, Fox CF: cAMP-dependent protein kinase stimulates epidermal growth factor-dependent phosphorylation of epidermal growth factor receptors. J Biol Chem 1984, 259:3864-3869.

9. Barbieri MA, Ramkumar TP, Fernandez-Pol S, Chen PI, Stahl PD: Receptor tyrosine kinase signaling and trafficking - paradigms revisited. Curr Top Microbiol Immunol 2004, 286: I-20.

10. Salazar G, Gonzalez A: Novel mechanism for regulation of epidermal growth factor receptor endocytosis revealed by protein kinase A inhibition. Mol Biol Cell 2002, I 3: I677-I693.

II. Corbin JD, Sugden PH, West L, Flockhart DA, Lincoln TM, McCarthy $D$ : Studies on the properties and mode of action of the purified regulatory subunit of bovine heart adenosine 3':5'monophosphate-dependent protein kinase. J Biol Chem 1978, 253:3997-4003.

12. Skalhegg BS, Tasken K: Specificity in the cAMP/PKA signaling pathway. Differential expression, regulation, and subcellular localization of subunits of PKA. Front Biosci 2000, 5:D678-D693.

13. Showers MO, Maurer RA: Cloning of cDNA for the catalytic subunit of cAMP-dependent protein kinase. Methods Enzymol 1988, I 59:3 | |-3 I8.

14. San Agustin JT, Leszyk JD, Nuwaysir LM, Witman GB: The catalytic subunit of the CAMP-dependent protein kinase of ovine sperm flagella has a unique amino-terminal sequence. J Biol Chem 1998, 273:24874-24883.

15. Uhler MD, Chrivia JC, McKnight GS: Evidence for a second isoform of the catalytic subunit of CAMP-dependent protein kinase. J Biol Chem 1986, 26 I:I5360-I5363.

16. Wiemann S, Kinzel V, Pyerin W: Isoform $\mathbf{C}$ beta 2, an unusual form of the bovine catalytic subunit of cAMP-dependent protein kinase. J Biol Chem I99I, 266:5I40-5 I46.

17. Guthrie CR, Skalhegg BS, McKnight GS: Two novel brain-specific splice variants of the murine Cbeta gene of cAMP-dependent protein kinase. J Biol Chem 1997, 272:29560-29565.

18. Orstavik S, Reinton N, Frengen E, Langeland BT, Jahnsen T, Skalhegg BS: Identification of novel splice variants of the human catalytic subunit Cbeta of cAMP-dependent protein kinase. Eur J Biochem 200I, 268:5066-5073.

19. Orstavik S, Funderud A, Hafte TT, Eikvar S, Jahnsen T, Skalhegg BS: Identification and characterization of novel PKA holoenzymes in human T lymphocytes. FEBS I 2005, 272: I559-| 567.

20. Kvissel AK, Orstavik S, Oistad P, Rootwelt T, Jahnsen T, Skalhegg BS: Induction of Cbeta splice variants and formation of novel forms of protein kinase A type II holoenzymes during retinoic acid-induced differentiation of human NT2 cells. Cell Signal 2004, 1 6:577-587
21. Howe DG, Wiley JC, McKnight GS: Molecular and behavioral effects of a null mutation in all PKA C beta isoforms. Mol Cell Neurosci 2002, 20:5 I5-524.

22. Skalhegg BS, Huang Y, Su T, Idzerda RL, McKnight GS, Burton KA Mutation of the Calpha subunit of PKA leads to growth retardation and sperm dysfunction. Mol Endocrinol 2002, 16:630-639.

23. Tasken K, Aandahl EM: Localized effects of cAMP mediated by distinct routes of protein kinase A. Physiol Rev 2004, 84: I 37-I67.

24. Skalhegg BS, Funderud A, Henanger HH, Hafte TT, Larsen AC, Kvissel AK, Eikvar S, Orstavik S: Protein kinase A (PKA) - a potential target for therapeutic intervention of dysfunctional immune cells. Curr Drug Targets 2005, 6:655-664.

25. Ekanger R, Vintermyr OK, Houge G, Sand TE, Scott JD, Krebs EG, Eikhom TS, Christoffersen T, Ogreid D, Doskeland SO: The expression of CAMP-dependent protein kinase subunits is differentially regulated during liver regeneration. J Biol Chem 1989 , 264:4374-4382

26. Davies SP, Reddy H, Caivano M, Cohen P: Specificity and mechanism of action of some commonly used protein kinase inhibitors. Biochem J 2000, 35 I:95-105.

27. Leemhuis J, Boutillier S, Schmidt G, Meyer DK: The protein kinase A inhibitor $\mathbf{H 8 9}$ acts on cell morphology by inhibiting Rho kinase. J Pharmacol Exp Ther 2002, 300:1000-1007.

28. Kato $Y$, Ozaki N, Yamada T, Miura Y, Oiso Y: H-89 potentiates adipogenesis in 3T3-LI cells by activating insulin signaling independently of protein kinase A. Life Science 2007, 80(5):476-483.

29. Cadd G, McKnight GS: Distinct patterns of cAMP-dependent protein kinase gene expression in mouse brain. Neuron 1989, 3:7I-79.

30. Huang Y, Roelink H, McKnight GS: Protein kinase A deficiency causes axially localized neural tube defects in mice. J Biol Chem 2002, 277:19889-19896.

31. Han P, Sonati P, Rubin C, Michaeli T: PDE7AI, a cAMP-specific phosphodiesterase, inhibits CAMP-dependent protein kinase by a direct interaction with C. I Biol Chem 2006, 28 I : I5050-I5057.

32. Ma Y, Pitson S, Hercus T, Murphy J, Lopez A, Woodcock J: Sphingosine activates protein kinase $A$ type II by a novel cAMP-independent mechanism. J Biol Chem 2005, 280:260 I I-260I7.

33. Arteaga CL: ErbB-targeted therapeutic approaches in human cancer. Exp Cell Res 2003, 284: I22-I30.

34. Tortora G, Ciardiello F: Protein kinase A as target for novel integrated strategies of cancer therapy. Ann N Y Acad Sci 2002, 968: 139-47.

35. Tortora G, Yokozaki H, Pepe S, Clair T, Cho-Chung YS: Differentiation of HL-60 leukemia by type I regulatory subunit antisense oligodeoxynucleotide of CAMP-dependent protein kinase. Proc Natl Acad Sci USA I99I, 88:20 I I-20I5.

36. Nesterova M, Cho Chung YS: Antisense-protein kinase A: a single-gene-based therapeutic approach. Nat Med 1997, I:528-533.

37. Tortora G, Ciardiello F: Targeting of epidermal growth factor receptor and protein kinase $A$ : molecular basis and therapeutic applications. Ann Oncol 2000, I I:777-783.

38. Funderud A, Henanger HH, Hafte TT, Amieux PS, Orstavik S, Skalhegg BS: Identification, cloning and characterization of a novel 47 kDa murine PKA $C$ subunit homologous to human and bovine Cbeta2. BMC Biochem 2006, 4(7):20

39. Huitfeldt HS, Hunt JM, Pitot HC, Poirier MC: Lack of acetylaminofluorene - DNA adduct formation in enzymealtered foci of rat liver. Carcinogenesis 1988, 9:647-652.

40. Roskoski R Jr: Assays of protein kinase. Methods Enzymo 1983 , 99:3-6. 